5 Rieche K. Carcinogenicity of antineoplastic agents in man. Cancer Treat Rev 1984;11:39-67. 6 Coleman CN, Williams CJ, Flint A, et al. Hematologic neoplasia in patients treated for Hodgkin's disease 1977. N Engl I Med 1977;297:1249-52.

Tester WJ, Kinsella TJ, Waller B, et al. Second malignant neoplasms complicating Hodgkin's disease: the National Cancer Institute experience. Foumal of Clinical Oncology 1984;2:762-9.

8 disease: the National Cancer Institute experience. Foumal of Clinical Oncology 1984;2:762-9. cancer treatment: an analysis of the surveillance, epidemiology, and end results program cancer treatment: an analysis of

9 Chak LY, Sikic BI, Tucker MA, Horns RC, Cox RS. Increased incidence of acute nonlymphocytic leukemia following therapy in patients with small cell carcinoma of the lung. Foumal of Clinical Oncology 1984;2:385-90.

a Redman JR, Vugrin DV, Arlin ZA, et al. Leukemia following treatment of germ cell tumors in man. Joumal of Clinical Oncology 1984;2:1080.

10 Lerner H, Marcovitz E, Schoenfeld D, Zaren H. Second malignancies diagnosed in patients receiving chemotherapy at the Pennsylvania Hospital. I Surg Oncol 1983;23:195-7.

11 Robins HI, Ershler WB, Gholam-Reza H, Dohlberg S, Arndt C. Acute non-lymphocytic leukaemia in breast cancer: therapy retated or de novo? Lancet 1980; ;:91-2.

2 Gastrointestinal Tumor Study Group. Adjuvant therapy of colon-results of a prospectively randomized trial. N Engl I Med 1984;310:737-43.

3 Reimer RR, Hoover R, Fraumeni JF, Young RC. Acute leukemia after alkylating-agent therapy of ovarian cancer. N Engl I Med 1977;297:177-81.

14 Sandberg AA, Abe S, Kowalczyk JR, Zedgenidze A, Takeuchi J, Kakati S. Chromosomes and causation of human cancer and leukaemia. L. Cytogenetics of leukemias chromosomes and causation of human cancer and leukaemia. L. Cy

15 Pedersen-Bjergaard J, Philip P, Pedersen NT, et al. Acute nonlymphocytic leukemia, preleukemia and acute myeloproliferative syndrome secondary to treatment of other malignan diseases. Cancer 1984;54:452-62.

\section{Why keep hospital clinical records?}

National Health Service hospital records are public records ${ }^{1}$ and the DHSS has issued guidance on their retention and destruction. ${ }^{2}$ The most recent DHSS guidelines recommended new minimum periods of retention for personal health records with a view only to their possible use in litigation. ${ }^{3}$ They did not, however, give guidance on the destruction of records.

The recommended minimum retention periods are 25 years for obstetric records; until the patient's 25 th birthday or eight years after the last entry if longer for records relating to children and young people (including paediatric, vaccination, and community child health service records); and 20 years for records relating to mentally disordered persons within the meaning of the Mental Health Act 1959, and taken from the date at which, in the opinion of the doctor concerned, the disorder has ceased or diminished to the point where no further care or treatment is considered necessary. For all other personal health records the minimum period is eight years after the conclusion of treatment, and the same minimum of eight years applies after the death of a patient (or, in the case of obstetric records, death of a child-but not of the mother).

For various reasons many hospital clinical records have survived beyond these minimum retention periods. Their storage, however, is causing immense problems-and these are becoming more acute as hospitals close down or find that the space taken by clinical records is not cost effective. For example, the Norfolk and Norwich Hospital, which has 762 beds, creates some 30000 new files every year. ${ }^{4}$ Merely handling this information and retrieving it for current use are the main occupations of most medical records officers, without their worrying about long term preservation. This problem of longer term preservation has already been recognised, and concern has been expressed intermittently over the years. This concern led in 1977 to a one day conference at the King's Fund Centre, which found that the threat to medical records was if anything more serious than had been assumed and concluded "that the danger to medical records was so great that it was not possible to rely on long term action by central authorities to amend and enforce official guidelines. In the short term it was essential that the various interest groups acting in partnership at the local level should pool their efforts to ensure vigilance in respect of the preservation of medical records, and to introduce practical schemes for their retrieval, safe deposit, and accessibility to scholars and medical workers" (C Webster, paper presented at conference 25 May 1977).

The conference did much to alert interested parties to the dangers of the destruction of medical records including clinical records: as a result various local initiatives were taken. A survey of hospital records undertaken by the Contemporary Medical Archives Centre at the Wellcome Institute for the History of Medicine found that many administrative records had found their way into local authority record offices; in some areas offices had been actively locating and acquiring archives from hospitals. Clinical records, however, were seen as a distinct and less attractive group, and many record offices specifically excluded them when taking in other materials.

The problem caused by clinical records was next faced by a committee under the chairmanship of Sir Duncan Wilson which was appointed by the Lord Chancellor to investigate the workings of certain provisions of the Public Records Acts. Its report was published in March $1981 .^{5}$ Its chapter on NHS records suggested that they were of value in both medical and associated scientific research and historical and social studies. The committee thought that "the long term value of clinical records is less clear cut than that of the administrative and non-medical NHS records." It recommended, however, that clinical records reserved for research should remain the responsibility of the health authorities, who should arrange for their housing and maintenance; that the DHSS should invite the Medical Research Council to convene an advisory group to identify NHS clinical records of research potential and that, after consultation with the Public Record Office, it should issue guidance to health authorities on the periods for which records should be retained for research purposes; and that the NHS should designate a specified record officer for each region to take responsibility for the general supervision and handling of its records. ${ }^{5}$

The government responded to this report with a White Paper. ${ }^{6}$ Accepting that guidance given to NHS authorities should be revised, this went on to state that "The revised guidance would also effectively remove clinical records of individual patients from the scope of the Public Records Act." The government has made no recommendations on the retention or destruction of clinical records except in so far as it recommends minimum retention periods for possible use in litigation.

So the problem remains: what should be done with these records? - and it becomes increasingly critical as more and more clinical records are created. Some hospitals (particularly teaching hospitals) have overcome the problem by microfilming. Some have resorted to computerisation of information, which brings additional problems for archivists and historians. But often a large amount of older material has survived, frequently in bound volumes, for which the cost of retrospective microfilming is thought to be unjustified.

Before any work can be done on seeking to improve the present haphazard arrangements affecting the survival of hospital clinical records, a vital question needs to be poseddo these records need to survive? Medical historians, epidemiologists, and others may well claim that they should and indeed must survive. They will recount stories such as the fortuitous survival of Richard Napier's 17th century case 
notes among the Elias Ashmole collection now at the Bodleian Library, Oxford, which have greatly increased our knowledge of medical treatment, astrology, and the social mores of the day. ${ }^{7}$ It is easier, however, to recognise papers as "historical" if they are over 100 years old. Hospital administrators and medical records officers have to run an efficient service and justify costs for the present, not some 100 years in the future. And archivists are caught in a similar difficulty, most being unable to house records of such bulk while recognising that they will have an unknown (but clearly comparatively limited) use by historians. Moreover, they pose administrative difficulties arising from their normal closure period of 100 years unless the permission of the relevant authority is given (to protect confidentiality). Indeed, the issue of confidentiality compounds the problems, and, for different reasons, confuses the debate on the preservation of clinical and case records. ${ }^{89}$

The fundamental question of use therefore needs to be asked, if not resolved. Dr Charles Newman has set out some of the potential uses of clinical case notes, suggesting that they should be kept for historical rather than scientific research. " "The real reason," he wrote, "why case-notes are such an important source is because the first records are made in notes of patients under actual investigation. The material for original papers, monographs and books is often collected from case-notes. So that not only are case-notes the earliest record; they are also the most complete. They contain, even, the details which never come to publication. In other words, they tell you what was really done to patients, and from this is to be derived the most trustworthy and complete assessment of what doctors believed and thought at any given time, and how their minds were working."

But it is impossible to predict all the ways that archives will be used in the future, and with so many records and problems all the interested parties must get together and advise those who are being forced to take the decisions about what to do with the records under their supervision. This is the aim of a symposium which is being organised by the Wellcome Institute for the History of Medicine and the King's Fund Centre, which will take place in May 1985.

Five choices have so far been identified. Firstly, hospital clinical records might be kept in their original format (in which case we have to ask where, and who would pay). Secondly, they might be sampled or selected (in which case how, and where should the sample or selection be kept?). Thirdly, they might be microfilmed (cost must be remembered). Or they might be destroyed when they are no longer needed for legal purposes or after some agreed period such as $\mathbf{3 0}$ years. Or, finally, they might be kept, sampled, microfilmed, or destroyed according to local initiative-at random. This is what happens at the moment.

The symposium will be limited to a few invited participants. Some readers of the $B M F$ may already have faced this problem and may think that there are strong reasons for keeping or destroying some or all of these records. Any suggestions on how the problem of hospital clinical records can best be tackled, or comments on the options that have been identified, would be welcome so that these can be discussed at the symposium. Informed debate is essential before decisions.

AlEXANDRA NiCOL Liaison officer

Public Record Office,

Kew, Richmond, Surrey TW9 4DU

JULIA SHEPPARD Archivist

Wellcome Institute for the History of Medicine, London NW1 2BP
1 Public Records Act 1958. Section 1.

2 National Health Service. Preservation and destruction of hospital records. HM(61)73.

Department of Health and Social Security; Health Services Management. Retention of personal health records (for possible use in litigation). HM(80)7.

4 Davidson N. A Cook's tour of records. Health and Social Services Joumal 1979;89:690-1.

5 Report of Committee appointed by Lord Chancellor. Modern public records: selection and access. London: HMSO, 1981. (Cmnd 8204.)

6 Lord Chancellor's Department. Modem public records. London: HMSO, 1982. (Cmnd 8531.)

7 Macdonald M. Mystical bedlam. Cambridge: CUP, 1981.

8 Lock S. A question of confidence. An editor's view. Br Med J 1984;288: 123-5.

9 Loudon I. A question of confidence. How it strikes a historian. Br Med $\mathcal{J} 1984$;288:125-6.

10 Newman C. Medical records. Archives 1959;4:1-8.

\section{Road safety report: brickbats and bouquets}

Despite the introduction of compulsory wearing of front seat belts road accidents still constitute a huge public health problem. Every day on our roads 19 people are killed and a thousand are injured, and the Department of Transport has estimated that the total cost to the country in 1982 including a notional sum for pain, grief, and suffering was $£ 2370 \mathrm{~m}$. As the Royal Society for the Prevention of Accidents has said, if all the accidents in a single day occurred in the same place then both government and the public would demand that something dramatic should be done to reduce the carnage.

The first report from the House of Commons Transport Committee on Road Safety is thus to be welcomed for bringing the problem back to public attention. ${ }^{1}$ We also welcome the committee's suggestion that the government should recognise its failure to coordinate the work of the many departments that have something to do with road safety and set up a standing royal commission on road safety. We are not, however, sanguine that this will happen because Mrs Thatcher has still to set up her first royal commission after almost six years in office.

The report contains many other excellent suggestions, but there are a few deficiencies. Most of the media attention has been focused on the proposal to experiment with raising speed limits on motorways to $80 \mathrm{mph}$. Compared with other measures that might have an effect on road safety (either good or bad) speed limits are probably not that important, but they have a great symbolic value. The red blooded libertarian sees it as his inalienable right to drive his sports car as fast as he wants, whereas the doctors and others who have to pick up the pieces cannot see that getting from London to Birmingham five minutes faster is worth even a sprained wrist. So it is disappointing that the committee should have suggested this experiment in raising speed limits: even its own arguments seem to lead to keeping them unchanged. It accepts that higher speeds means more and worse accidents, but it muddles the statement by saying that the "relationship cannot be determined precisely." But hard evidence is available that higher speeds mean more deaths and accidents. ${ }^{2-5}$ Energy dissipated and stopping distance increase with the square of the speed; both are doubled when the speed rises from 60 to $82 \mathrm{mph}$.

Speed limits were reduced twice in Britain during the fuel crises of 1973-5, and both times there were reductions in deaths and accidents which could not be explained away by reduced traffic or other factors. ${ }^{45}$ All the decreases that have occurred in speed limits in Britain, the United States, France, and West Germany have led to reductions in accidents, and the lifting of all speed limits on German motorways in 1974 was followed by an $18 \%$ increase in deaths. ${ }^{2}$

What is more, the committee provides evidence that many motorists do not want the speed limit raised. The Auto- 